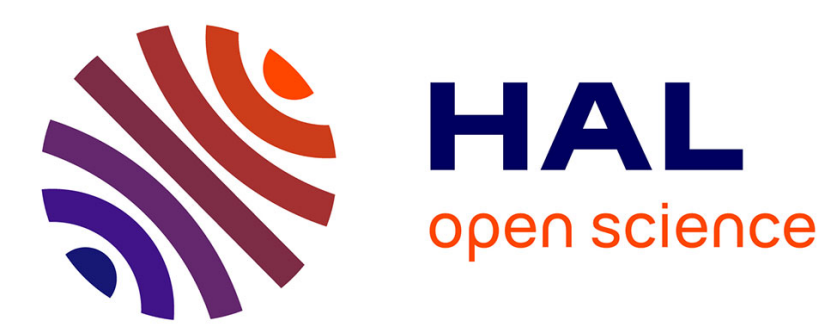

\title{
Stochastic model construction of natural hazards given experimental measures
}

\author{
F. Poirion
}

\section{To cite this version:}

F. Poirion. Stochastic model construction of natural hazards given experimental measures. 11th International Conference on Structural Safety \& Reliability (ICOSSAR 2013), Jun 2013, NEW YORK, United States. hal-01057497

\section{HAL Id: hal-01057497 \\ https://hal-onera.archives-ouvertes.fr/hal-01057497}

Submitted on 22 Aug 2014

HAL is a multi-disciplinary open access archive for the deposit and dissemination of scientific research documents, whether they are published or not. The documents may come from teaching and research institutions in France or abroad, or from public or private research centers.
L'archive ouverte pluridisciplinaire HAL, est destinée au dépôt et à la diffusion de documents scientifiques de niveau recherche, publiés ou non, émanant des établissements d'enseignement et de recherche français ou étrangers, des laboratoires publics ou privés. 


\title{
Stochastic model construction of natural hazards given experimental measures.
}

\author{
F. Poirion
}

11th International Conference on

Structural Safety \& Reliability

(ICOSSAR 2013)

NEW YORK, U.S.A

16-20 juin 2013

TP 2014-27

\section{ONERA}

THE FRENCH AEROSPACE LAB 

Stochastic model construction of natural hazards given experimental measures.

Construction de modèles stochastiques de phénomènes naturels à partir de mesures expérimentales.

par

F. Poirion

\section{Résumé traduit :}

On s'intéresse ici à la constructions de modèles stochastiques réalistes pour représenter les phénomènes naturels. ces modèles, basés sur la représentation de Karhunen Loève des processus du second ordre non stationnaires ainsi que sur l'utilisation de noyaux gaussiens, nécessitent l'existence de bases de données expérimentales. Ces approches sont mise en oeuvre sur des exemples académiques ainsi que sur une base de données de séismes. 



\title{
STOCHASTIC MODEL CONSTRUCTION OF NATURAL HAZARDS GIVEN EXPERIMENTAL MEASURES
}

\author{
Fabrice Poirion \\ ONERA The French Aerospace Lab \\ BP 72, 92322 Chatillon, FRANCE \\ poirion@onera.fr \\ Irmela Zentner \\ LaMSID, UMR EDF-CNRS-CEA \\ 1 Avenue du Général de Gaulle, 92140 Clamart, FRANCE \\ irmela.zentner@edf.fr
}

The formidable progress of computer technology has given manufacturers access to Monte Carlo simulation (MCS) methods for studying real life industrial problems. But in order to obtain reliable results, realistic models have to be fed in the numerical procedures: the airplane manufacturer needs realistic gust models, nuclear engineers need realistic seismic models, etc.

Over the last decade a relatively important number of scientific papers has dealt with construction of non-Gaussian models in order to mimic the natural world. This evolution between the standard Gaussian models to non-Gaussian ones is not a surprise since an evergrowing number of experimental measures has highlighted the non-Gaussian properties of natural phenomena. It is indeed the case in the oceanographic world, in geophysics, for earthquakes, wind in the atmospheric boundary layer, in astrophysics and even in the medical domain where non-Gaussian stochastic models are proposed for electrocardiograms.

In this context, an important effort has been made in order to develop numerical methods for simulating non-Gaussian processes, essentially stationary processes, even if some rare methods were proposed for the non-stationary case. Construction of non-Gaussian models is a very difficult task since a non-Gaussian process is characterized by its infinite family of joint distributions .

Various methods have been proposed for generating simulated paths of stationary non-Gaussian real valued processes which aim is to reproduce only the power spectral density and the first order marginal distribution of the target process.

Dealing with non-stationary processes is a more difficult challenge since the marginal distributions depends on time and since the power spectral density does not exist any longer. A few number of papers describe approaches which could be used in this context. The construction of a probabilistic models is achieved either by fitting the variability of the phenomenon to an analytical, given probabilistic model (based on physics, Bayesian considerations or information 
theory) or by constructing models which replicates statistical characteristics which have been observed, without making any assumptions on the probability distribution.

The goal of this paper is to propose a simple stochastic model based on Karhunen Loève representation, capable of describing the non-stationary and uncertain behaviour of a time dependent phenomenon based on a given set of observations. Dependency between the random variables appearing in the Karhunen Loève representation is introduced through a pairwise selection using the Kullback dependency measure. Examples are given on academic examples and an application related to peak value distribution of ground acceleration illustrates the good assessment between the model and the measured accelerograms compared to classical Gaussian models.

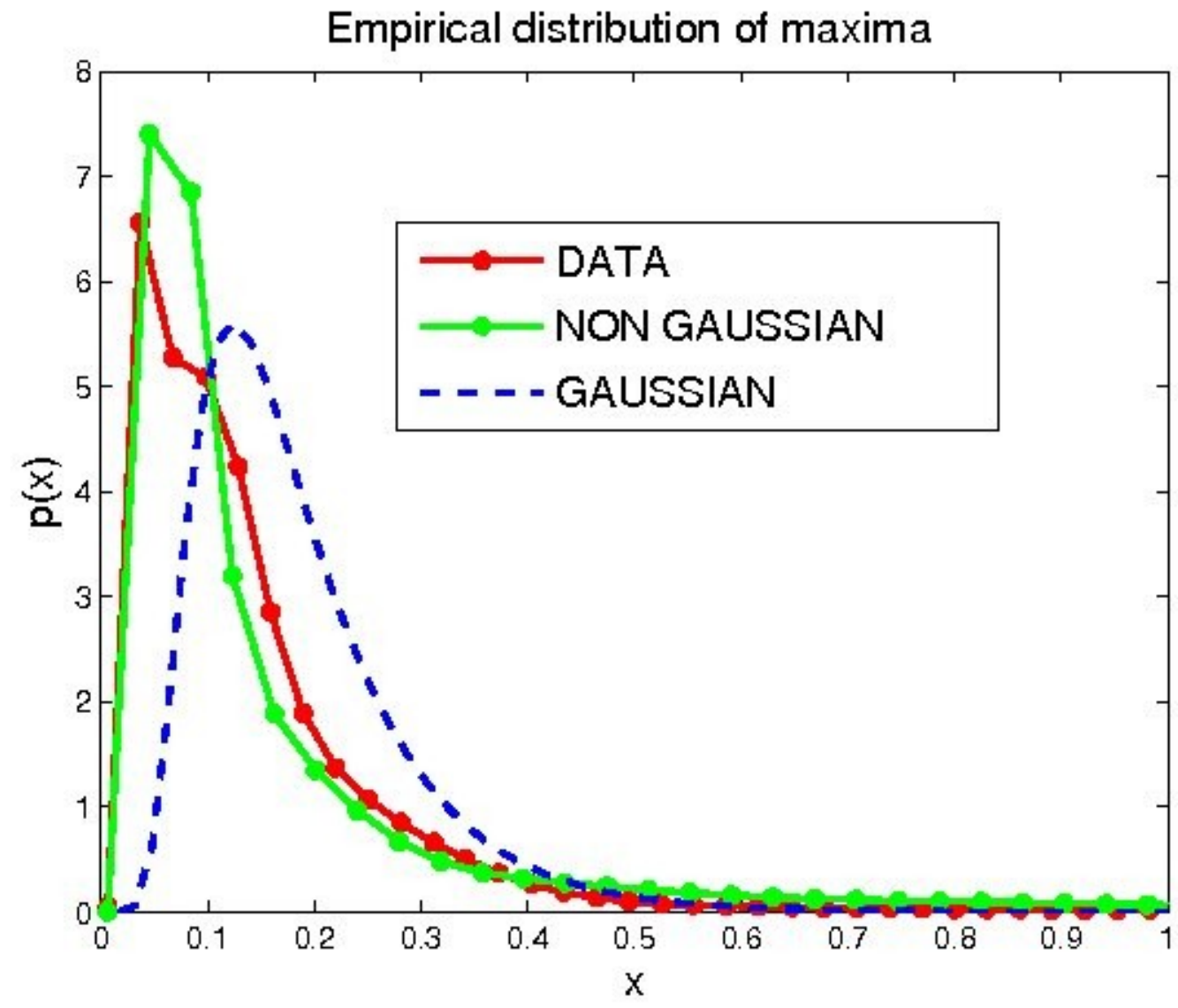





\section{ONERA}

BP 72 - 29 avenue de la Division Leclerc - 92322 CHATILLON CEDEX - Tél. : +33 146734040 - Fax : +33 146734141

w w w. onera.f r 